\title{
FOOD ALLERGY KNOWLEDGE AND PRACTICE OF RESTAURANT STAFF
}

\author{
Jekaterina Bujaka*, Rita Riekstina-Dolge \\ Department of Nutrition, Faculty of Food Technology, Latvia University of Life Sciences and Technologies, Rigas iela 22, \\ Jelgava, Latvia, e-mail: rita.riekstinadolge@gmail.com
}

\begin{abstract}
Nowadays people more and more often choose to have their meals outside their homes. Therefore, the catering companies shall ensure safe product offer to different guest groups, including guests with food allergy or intolerance. Alongside with the tendency of the increase of allergic people's number, there have been corrections introduced to the European Union legislation in relation to the product labelling. It means that at present one of the compulsory types of information that shall be indicated by catering companies is information on the presence of allergens in food. It is stipulated by Regulations (EC) No 1169/2011 on the provision of food product information to consumers. One of the reasons why allergic reaction to food takes place at catering companies is the lack of knowledge of staff. Therefore, the aim of research was to determine the level of staff's knowledge and to analyse the types of allergen indications at the catering companies. Twenty catering companies took part in the study, there were 60 companies addressed in total, and 154 valid questionnaires were received. The main research results show that the staff has incomplete knowledge (on average $3.8 \pm 1.8$ out of 10), as well as not all catering companies indicate information on the presence of allergens in the food.
\end{abstract}

Keywords: knowledge, food allergies, intolerances, allergen labelling

\section{Introduction}

During the last years the number of people with food allergy has increased and it has become a serious global problem. In total, 17 millions of Europeans and 15 millions of Americans suffer from this illness (FARE, 2018; EAACI 2013). Food allergy is more often observed among children (5-8\%) than adults (1-2\%) (WAO, 2013).

There has been a general term determined to denote such and similar undesirable body reactions to food - adverse reaction to food (Pulido, 2010). The researchers are not unanimous how to classify such reactions, therefore classifications used by several organizations differ.

In this article there has been used EAACI classification used by Polish researchers, where the reactions are grouped into toxic (food infections, intoxication), immunological (food allergy), non - immunological (food intolerance) (Bartuzi et al., 2017).

Food allergy is an excessive reaction of immune system to product substances. Allergic reactions are more often caused by protein. Food allergy often is confused with food intolerance due to similar symptoms; however, the difference of food intolerance is that the immune system is not involved in reactions. Taking into consideration the increase of the number of allergic people, there have been corrections made to the legislation in relation to product labelling. Any company of food circulation, if it is responsible for provision of product information for consumers, shall provide "compulsory information of food products" that, in conformity with the Union regulations, comprises also the information on the presence of allergens in products (Regulation (EC) No 1169/2011 of the European Parliament and of the Council, 2011). It is established during the research that most of the food allergy cases are caused by non-prepacked food products or consuming food at any catering companies (Barnett et al., 2011; Peniamina et al., 2016). It means that at the catering companies information on food allergens (14 product and substance groups) shall be available and indicated in an easy to perceive form, it should be highlighted, legible and non-erasable, before the purchase of food/product in order consumers, especially those suffering from food allergy or intolerance could make informed and safe choice (Regulation (EC) No 1169/2011).

Labelling cannot guarantee that by consuming the product of catering company the guest will not face any of undesirable reactions to food. The consumer's confusions and uncertainty in relation to presence of allergens might negatively affect Health Related Quality of Life (HRQL), which could even more aggravate the insufficient understanding shown by employees of restaurants, coffee-bars (Barnett et al., 2011). The studies performed showed that most often reasons why there is reaction to food at the catering companies is the lack of staff's knowledge, cross-contact, incorrect labelling, communication problems that take place between a guest and the staff, as well as the lack of communication among the members of the staff (Blom et al., 2018; Lee, Sozen, 2016). At the Latvian catering companies, it is possible to observe different forms of allergen labelling. As one of them is a phrase in the menu "Ask the waiter about allergens" that binds the waiters to be informed on the types of allergens and their presence in the food.

Unfortunately, there are no precise statistical data on the number of people suffering from food allergy and intolerance in Latvia. As well as there are no detailed studies on the issue of food allergens, their influence on the performance of catering companies. The aim of this work is to find out how catering companies indicate information on the presence of allergens specified in Annex II to Regulations (EC) No.1169/2011 and on the level of catering company staff's knowledge on food allergies and intolerance. 


\section{Materials and Methods}

Analysis of Information References of Allergens

There were 4 criteria developed for the evaluation of menus in conformity with Regulation (EC) Nr.1169/2011 on the provision of food information to consumers, in conformity with general conditions in relation to the labelling of compulsory information, as well as an additional criterion (5) in relation to the presence of alternatives at companies, for people with allergy or intolerance. In total there were 54 companies visited in Riga and Jelgava, out of which 20 were restaurants, 20 - coffee-bars and 14 - fast-food companies (including canteens).

\section{Questionnaires}

There were three types of questionnaires developed: one for cooks, one for waiters and one for managers. The questionnaires consisted of three parts: demographic information, information on the company, the part on knowledge. All questionnaires had identical questions within part on knowledge and part on demographic information, but the part on information about the company was different for managers' questionnaire. Part on knowledge consisted of 10 questions, to which the respondent answered by choosing 1 out of 5 answers (a Likert scale): 1 - yes; 2 - rather yes than no; 3 - I don't know; 4 - rather no than yes; 5 - no. The correct answers were codified with a digit 1, the wrong answers were codified with 0 . The answers Yes or No were considered as correct. If the respondent answered to the question by Rather Yes than No, I don't know, Rather No than Yes, the answers were considered as incorrect, because they show that the respondent is not sure for his or her answer.

\section{Selection of respondents}

There were 60 public catering companies addressed selected in Riga according to random choice; they offer waiters' services. 20 companies participated in the research; from them there were 154 valid questionnaires obtained. There were waiters and cooks $(n=139)$, as well as managers $(n=15)$ involved in the survey.

\section{Summarizing and analysis of results}

MS Excel 2013 software was used for data processing. The following elements of descriptive statistics were used for summarizing the results - the mean arithmetical and the standard deviation. In order to determine the influence of factors, t-test was used: two-sample equal/unequal variance and ANOVA (single factor). The significance level was determined as $\mathrm{p}<0.05$.

\section{Results and Discussion}

The analysis of the allergen information labelling types Most of the visited catering companies or $51.9 \%(n=28)$ had indicated no information on allergens in their menus, on separate stands or in booklets (Table 1), but 14 of these companies had only indicated the phrase "Ask the waiter about allergens". The allergens weren't more often indicated at the cafes $(65 \%)$, less - at the restaurants $(45 \%)$. Of those companies that could perform the full analysis of criteria, $48.1 \%$ companies indicated allergens in a form of codes, for example, A1, 01,1, b, A. $13.3 \%$ companies indicate allergen information by using the group names specified in Annex II to Regulation (EC) No.1169/2011, for example, wheat, eggs, nuts. But $39.1 \%$ of companies in their menus or in other types of annexes, in addition to the group names indicated in the regulatory enactments, add also a phrase "Ask the waiter about the detailed allergen information", $49.8 \%$ of companies have used the size of digits or codes to indicate the allergens, where the size is smaller than or equal to $1.2 \mathrm{~mm}$ and thus there was some difficulties to read and perceive information. $34.9 \%$ of allergen information was easy to perceive, read, and the font, as well as the size of letters used was appropriate. In $34.9 \%$ cases the colour of letters or codes used for information sufficiently differed from the background of menu or other type of annex, thus such information was easy to read. But in $56.5 \%$ of the cases the colour of letters or codes used by companies only slightly differed from the background of menu or another annex that caused insignificant difficulty to see and read the information. Most of the companies or $65.5 \%$ do not offer alternatives for the guests with food allergies or intolerances. The alternative products, dishes that have been adjusted for the guests with allergies or intolerance are offered in the menus of $54.5 \%$ of restaurants. On the whole, there were no significant differences $(\mathrm{p}=0.05)$ found between the types of companies regarding the allergen information labelling.

\section{Analysis of survey data}

The total number of respondents was 154 out of whom $40.9 \%$ were cooks, waiters $-49.4 \%$, but managers $9.7 \%$ (Table 2). $60.4 \%$ of waiters/cooks and $86.7 \%$ of managers have indicated that daily they often attend guests with food allergy or intolerance (on average 4.2 \pm 2.9 times per week). More than a half of the responding waiters/cooks $(52.5 \%)$ confirm that they have participated in the training related to food allergies and/or intolerances. When answering the question: "Do the guests with food allergies and intolerances cause inconveniences?", $64.7 \%$ of waiters/cooks answered "No", but $35.3 \%$ answered "Yes"; in addition, they were asked to provide detailed explanation for the chosen variant of the answer. The respondents who chose the variant "Yes", most often as the factors of inconveniences related to attending the guests with food allergies or intolerances indicate time ("Longer period of attending", "There should be changed the calculation of the dish", "Breaks the rhythm", "It is necessary to think what dishes could be offered, or to choose such alternatives that preserve the qualities of the dish"), emotional factor ("Such guests cause stress", "I should be careful, it is additional responsibility", "There should extra work done"), shortage of resources ("There are no appropriate substituting products", "We have no tendency towards allergic guests", "There is a narrow choice of dishes we can offer"), guests ("The guests are not able to explain properly what kind of allergy or 
intolerance they have", "Sometimes people tell about the allergy too late", "Very often allergy is combined with veganism"), lack of knowledge ("There is lack of knowledge about food allergies or intolerances"). But those respondents who have no inconveniences in relation to attending allergic guests, most often indicate emotional factor ("They are also people", "It is not their fault that they have allergy or intolerance", "There is always a way out of the situation", "It is our job to attend all guests equally", "We should anticipate what allergies people might have, therefore we should consider alternatives", "We are professionals", "I do not attend such guests", "Because it makes the job different", "It is my job").
Upon the commencement of work, 50.4\% of waiters/cooks have not received oral or written instructions from an employer how to attend guests with food allergy or intolerance. More than a half of the managers $(66.7 \%)$ have responded that there have been no standards elaborated at the company how to attend guests with food allergy or intolerance. When answering the question "What do you think - is the food allergy and intolerance a topical problem in the catering industry?", most of the respondents - waiters / cooks $(86.3 \%)$ and managers $(80 \%)$ - have indicated that it is a topical problem.

Allergen indication evaluation of menus

\begin{tabular}{|c|c|c|c|c|}
\hline \multirow{2}{*}{$\begin{array}{l}\text { Criterion } \\
\text { code }\end{array}$} & \multirow[b]{2}{*}{ Criterion } & \multicolumn{3}{|c|}{ Allergen indications \% } \\
\hline & & $\begin{array}{c}\text { Restaurants } \\
(\mathbf{n}=\mathbf{2 0})\end{array}$ & $\begin{array}{c}\text { Cafe } \\
(\mathbf{n}=20)\end{array}$ & $\begin{array}{c}\begin{array}{c}\text { Fast food restaurants } \\
(\mathrm{n}=14)\end{array} \\
\end{array}$ \\
\hline 1 & Information placement position & & & \\
\hline 1.1. & Allergen information is not provided & 45.0 & 65.0 & 42.9 \\
\hline 1.2. & $\begin{array}{l}\text { Allergen groups are listed on the separate sheet, but there } \\
\text { is no information on their content in food }\end{array}$ & 5.0 & 0.0 & 21.4 \\
\hline 1.3. & Allergen information is on a separate stand or booklet & 5.0 & 10.0 & 14.3 \\
\hline 1.4 . & $\begin{array}{l}\text { The information is on the menu as a separate page in the } \\
\text { beginning or end page in menu }\end{array}$ & 35.0 & 15.0 & 14.3 \\
\hline 1.5 . & $\begin{array}{l}\text { The information is on the menu next to the name of each } \\
\text { meal }\end{array}$ & 10.0 & 10.0 & 7.1 \\
\hline 2 & The amount of information & $\mathbf{N}=\mathbf{1 3}$ & $\mathbf{N}=9$ & $\mathbf{N}=\mathbf{8}$ \\
\hline 2.1. & $\begin{array}{l}\text { In the menu/ a stand/ booklet the phrase - „Ask the waiter } \\
\text { about allergens” }\end{array}$ & 15.4 & 22.2 & 25.0 \\
\hline 2.2 . & $\begin{array}{l}\text { Allergens at each meal are indicated by symbols or codes } \\
\text { (e.g. A01; } 1 \text { a) }\end{array}$ & 61.5 & 44.4 & 25.0 \\
\hline 2.3 . & $\begin{array}{l}\text { Allergens at each meal are indicated by symbols or codes } \\
\text { as well as the phrase „Ask the waiter about allergens" }\end{array}$ & 0.0 & 0.0 & 0.0 \\
\hline 2.4 . & $\begin{array}{l}\text { Allergens at each meal are indicated by group names } \\
\text { (wheat, eggs, milk) }\end{array}$ & 0.0 & 22.2 & 25.0 \\
\hline 2.5 . & $\begin{array}{l}\text { Allergens at each meal are indicated by group names as } \\
\text { well as the phrase „Ask the waiter about allergens” }\end{array}$ & 23.1 & 11.1 & 25.0 \\
\hline 3 & A letter or code size and used font & $\mathbf{N}=\mathbf{1 1}$ & $\mathrm{N}=7$ & $\mathbf{N}=5$ \\
\hline 3.1. & $\begin{array}{l}\text { A letter or code size is less than } 1.2 \mathrm{~mm} \text {, used font makes } \\
\text { it difficult to the perceiving and reading }\end{array}$ & 0.0 & 0.0 & 0.0 \\
\hline 3.2. & $\begin{array}{l}\text { A letter or code is equal to } 1.2 \mathrm{~mm} \text {, used font makes it } \\
\text { difficult to the perceiving and reading }\end{array}$ & 63.6 & 28.6 & 20.0 \\
\hline 3.3 . & $\begin{array}{l}\text { A letter or code is greater than } 1.2 \mathrm{~mm} \text {, used font makes it } \\
\text { difficult to the perceiving and reading }\end{array}$ & 9.1 & 28.6 & 20.0 \\
\hline 3.4 . & $\begin{array}{l}\text { A letter or code is equal or greater than } 1.2 \mathrm{~mm} \text {, used font } \\
\text { does not affect to the perceiving and reading }\end{array}$ & 27.3 & 42.9 & 60.0 \\
\hline 4 & $\begin{array}{l}\text { Visibility of letters or codes or codes against the } \\
\text { background }\end{array}$ & $\mathbf{N}=11$ & $\mathrm{~N}=7$ & $\mathbf{N}=5$ \\
\hline 4.1. & $\begin{array}{l}\text { The letters or code blends with the background of the menu } \\
\text { or stand or booklet. Cannot be perceived. }\end{array}$ & 9.1 & 0.0 & 0.0 \\
\hline 4.2 & $\begin{array}{l}\text { The colour of letters or code is different from the } \\
\text { background of a menu or booklet. It is difficult to perceive. }\end{array}$ & 63.6 & 57.1 & 40.0 \\
\hline 4.3. & $\begin{array}{l}\text { The colour of letters or code differs essentially from the } \\
\text { background of a menu or booklet. Easy to perceive or read. }\end{array}$ & 27.3 & 42.9 & 60.0 \\
\hline 5 & The existence of alternative & $\mathbf{N}=\mathbf{1 1}$ & $\mathrm{N}=7$ & $\mathbf{N}=5$ \\
\hline 5.1. & $\begin{array}{l}\text { The company does not offer alternatives to guests with food } \\
\text { allergy or intolerance }\end{array}$ & 45.0 & 100 & 100 \\
\hline 5.2. & $\begin{array}{l}\text { The company offers alternative products for guests with } \\
\text { food allergies or intolerances }\end{array}$ & 54.5 & 0.0 & 0.0 \\
\hline
\end{tabular}


Table 2

Demographical information

\begin{tabular}{|c|c|c|}
\hline Variable & $\begin{array}{c}\text { Number of } \\
\text { respondents }\end{array}$ & $\begin{array}{c}\text { Percentage, } \\
\%\end{array}$ \\
\hline Gender & $N=154$ & \\
\hline female & 88 & 57.1 \\
\hline male & 66 & 42.9 \\
\hline Education & $N=154$ & \\
\hline Middle school graduate & 9 & 5.8 \\
\hline High school graduate & 36 & 23.4 \\
\hline $\begin{array}{l}\text { High professional } \\
\text { graduate }\end{array}$ & 73 & 47.4 \\
\hline $\begin{array}{l}\text { College (university) } \\
\text { graduate }\end{array}$ & 36 & 23.4 \\
\hline Age & $N=154$ & \\
\hline$<18$ & 4 & 2.6 \\
\hline $19-35$ & 119 & 77.3 \\
\hline $36-45$ & 21 & 13.6 \\
\hline$>45$ & 10 & 6.5 \\
\hline Position & $N=154$ & \\
\hline cook & 63 & 40.9 \\
\hline waiter & 76 & 49.4 \\
\hline manager & 15 & 9.7 \\
\hline $\begin{array}{l}\text { Work experience in } \\
\text { hospitality }\end{array}$ & $N=154$ & \\
\hline$<1$ year & 27 & 17.5 \\
\hline $1.1-7$ years & 70 & 45.5 \\
\hline$>7.1$ years & 57 & 37 \\
\hline
\end{tabular}

Cooks and waiters were asked an additional question: "Do you have food allergy or intolerance?", where $13.7 \%$ had indicated that they had, but $86.3 \%$ indicated that they had no such problem. $70.5 \%$ of waiters / cooks have indicated that their represented company specify allergens in menus, but $9.4 \%$ do not know, whether information on allergens have been specified. $64.7 \%$ of waiters/cooks and $86.7 \%$ of managers have confirmed that the company offers different alternatives to guests with food allergy or intolerance (specialized menu or dishes, substituting products etc.).

Although more than a half of waiters/cooks (74.8\%) found that they have sufficient knowledge of menu offered at the company in order to assist guests with food allergy or intolerance, the results show that the personnel lacks insight into the theoretical aspects of food allergy and intolerance (Table 3 ).

Only $1.3 \%$ of respondents in the part of knowledge had obtained 9 correct answers out of 10 . The respondents' mean number of correct answers was $3.8 \pm 1.8$ out of 10 . Most of the problems the respondents had regarding the questions related to determining the difference between food allergy and intolerance (statements C and G). Only $27.3 \%$ (statement C) of respondents knew that food allergy and intolerance is not one and the same. In other studies the respondents also often make mistakes regarding such similar questions (Soon, 2018). However, the insight into such issues is necessary. Food allergies are mostly related to the functioning of immune system and in some cases they might become a reason for death.

Table 3

Respondents' knowledge about food allergies and intolerances

\begin{tabular}{|c|c|c|c|c|c|c|c|}
\hline \multirow[b]{2}{*}{ Statement code } & \multicolumn{4}{|c|}{ Respondents' answers, \% $(n=154)$} & \multicolumn{3}{|c|}{ Mean indicators } \\
\hline & Yes (1) & $\begin{array}{l}\text { Rather Yes } \\
\text { than No (2) }\end{array}$ & $\begin{array}{l}\text { I don't } \\
\text { know (3) }\end{array}$ & $\begin{array}{l}\text { Rather No } \\
\text { than Yes (4) }\end{array}$ & No (5) & Mean & SD \\
\hline $\begin{array}{l}\text { Food allergy is caused by enzyme } \\
\text { deficiency }(\mathrm{A})\end{array}$ & 29.9 & 24.7 & 31.8 & 8.4 & $5.2 \mathrm{a}$ & 2.4 & 1.2 \\
\hline $\begin{array}{l}\text { Legislation provides for the } \\
\text { compulsory indication of allergens in } \\
\text { the menus (B) }\end{array}$ & 69.5 & 9.1 & 9.1 & 2.6 & $9.7 \mathrm{a}$ & 1.8 & 1.3 \\
\hline $\begin{array}{l}\text { Food intolerance is the same as food } \\
\text { allergy (C) }\end{array}$ & 12.3 & 24.7 & 24.0 & 11.7 & $27.3 \mathrm{a}$ & 3.2 & 1.4 \\
\hline $\begin{array}{l}\text { Food allergy occurs only by eating an } \\
\text { allergic product (D) }\end{array}$ & 20.1 & 14.3 & 7.1 & 16.2 & $42.2 \mathrm{a}$ & 3.5 & 1.6 \\
\hline $\begin{array}{l}\text { A small amount of an allergic product } \\
\text { does not cause an allergic reaction (E) }\end{array}$ & 5.2 & 9.1 & 10.4 & 16.9 & $58.4 \mathrm{a}$ & 4.2 & 1.2 \\
\hline Food Allergy Can Be Fatal (F) & $76.6 \mathrm{a}$ & 8.4 & 7.8 & 5.2 & 2.0 & 1.5 & 1.0 \\
\hline $\begin{array}{l}\text { Lactose intolerance is the same as milk } \\
\text { allergy }(\mathrm{G})\end{array}$ & 48.7 & 16.2 & 7.1 & 3.9 & $24.0 \mathrm{a}$ & 2.4 & 1.7 \\
\hline $\begin{array}{l}\text { In case of food intolerance, you should } \\
\text { refuse to use the product }(\mathrm{H})\end{array}$ & $62.3 \mathrm{a}$ & 20.8 & 8.4 & 5.2 & 3.3 & 1.7 & 1.1 \\
\hline $\begin{array}{l}\text { Symptoms of food intolerance are } \\
\text { anaphylactic shock (I) }\end{array}$ & 22.1 & 15.6 & 35.7 & 12.3 & $14.3 \mathrm{a}$ & 2.8 & 1.3 \\
\hline $\begin{array}{l}\text { If a guest is allergic to nuts and he } \\
\text { orders a dessert containing nuts, it is } \\
\text { enough to remove them from the } \\
\text { portions to make the food safe for the } \\
\text { client }(\mathrm{J})\end{array}$ & 10.4 & 4.6 & 5.2 & 7.8 & $72.1 \mathrm{a}$ & 4.2 & 1.4 \\
\hline
\end{tabular}


Besides, the reaction might be caused also just by touching the product or inhaling its vapours. The staff that has an important role at the catering company for the communication with a guest shall be ready to identify allergy symptoms and to provide timely assistance during the reaction (Dupuis et al, 2016). The respondents made mistakes while answering the statement B, where only $9.7 \%$ of respondents have correctly indicated that legislation does not provide for compulsory allergen labelling in the menu. Regulation (EC) No.1169/2011 on the provision of food product information to consumers provides that the allergen information shall be provided in writing, but it is up to the company, where such information would be displayed. Most of the respondents (76.6\%) answered correctly that food allergy may be lethal. There should be also statement $\mathrm{J}$ pointed out, where $72.1 \%$ of respondents gave the correct answer. There were calculations performed using ANOVA and $\mathrm{t}$ - test in order to find out, whether there are differences between the influence of different factors and the results of knowledge. In relation to such factors as a position $(p=0.153)$, existence/lack of training $(p=0.182)$ and the fact, whether respondent has or has no allergy/intolerance $(p=0.940)$, there was not observed significant influence on the results of knowledge. The influence of position has not been statistically significant factor in relation to the results of knowledge also in the studies performed by Lee, Sozen (2016), Soon (2018) and Shafie, Azman (2015). However, Lee, Sozen (2016) in the study found significant differences between those respondents who had training and who had no training. In the authors' study the respondents were not asked more detailed questions about the content, duration and other indicators of training; thus, it is necessary to perform additional studies to find out and assess the quality of training.

However, answering why the results of knowledge are not influenced also by existence or non-existence of allergy/intolerance could be found in the fact that there was no detailed division indicated in the study for the answers provided to question: "Do you have food allergy or intolerance?" Thus, the respondents who had intolerance could lack knowledge of allergy issues, but the respondents with allergy could lack knowledge of intolerance issues. There is also a question, whether the particular respondent really has food allergy or intolerance.

\section{Conclusions}

Thoughtful management of food allergens in restaurants is a topical issue in Latvia. Overall $51.9 \%$ of visited companies do not indicate any information on the presence of allergens in the food. Indication "Ask the waiter about allergens" cannot be sufficient for the provision of allergen information. Servicing staff is responsible for correct allergen information explanation to a guest and its further transfer to members of staff working in the kitchen. Research data show that the respondents' knowledge could be evaluated as poor, there is no insight into the food intolerance and allergy difference. The level of knowledge is not significantly different among managers, cooks and waiters. It is not influenced also by existence or lack of training. Such tendency may endanger population's health with allergens and intolerance. This issue is complicated and difficult, and there are further studies needed in order to explain reasons for the careless attitude of catering company managers and employees towards the provision of allergen information at the company.

\section{References}

1. Barnett J, Leftwich J, Muncer K, Grimshaw K, Shepherd R, Raats M.M, Gowland M.H, Lucas JS. (2011) How do peanut and nut allergic consumers use information on the packaging to avoid allergens? Allergy, Vol. 66, p. 969-978.

2. Bartuzi Z., Kaczmarski M., Czerwionka-Szaflarska M., Malaczynska T., Krogulska A. (2017) Position paper of food allergy section the Polish society of allergology on the diagnosis and management of food allergies. Alergologia Polska - Polish Journal of Allergology, Vol. 4(3), p. 109-122.

3. Blom W. M., Michelsen-Huisman A. D., van OsMedendorp H., van Duijn G., de Zeeuw-Brouwer M., Versluis A., Castenmiller J. J. M., Noteborn H. P. J. M., Kruizinga A. G., Knulst A. C., Houben G. F. (2018) Accidental food allergy reactions: Products and undeclared ingredients. Journal of Allergy and Clinical Immunology, Vol.142 (3), p. 865-875.

4. Dupuis R., Meisel Z., Grande D., Strupp E., Kounaves E., Graves A., Frasso R., Cannuscio C. C. (2016) Food allergy management among restaurant workers in a large U.S. city. Food Control, Vol. 63, p. 147-157.

5. Lee Y. M., Sozen E. (2016) Food allergy knowledge and training among restaurant employees. International Journal of Hospitality Management, Vol. 57, p. 52-59.

6. Peniamina R. L., Peniamina R. L., Mirosa M., Bremer P., Conner T. S. (2016). The stress of food allergy issues in daily life. Psychology \& Health, Vol. 31(6), p.750-767.

7. Pulido O. M. (2010) Immune - mediated adverse reactions to dietary proteins. In: Allergen Management in the Food Industry. J. I. Boye, S. B. Godefroy (eds). Canada: John Wiley \& Sons, Inc., p. 3-33.

8. Shafie A. A., Azman A. W. (2015) Assessment of knowledge, attitude and practice of food allergies among food handlers in the state of Penang, Malaysia. Public Health, Vol. 129 (9), p. 1278-1284.

9. Soon J. M. (2018) "No nuts please": Food allergen management in takeaways. Food Control, Vol. 91, p. 349-356.

10. EAACI (2013) Food Allergy and Anaphylaxis Guidelines. [accessed on 17.01.2019.]. Available at: http://www.eaaci.org/foodallergyandanaphylaxisguidelin es/Food\%20Allergy\%20-\%20web\%20version.pdf

11. FARE (2018) Food Allergy Facts and Statistics for the U.S. [accessed on 17.01.2019.]. Available at: https://www.foodallergy.org/sites/default/files/2018-04/ FARE-Food-Allergy-Facts-Statistics.pdf.

12. Regulation (EC) No $1169 / 2011$ of the European Parliament and of the Council (2011). [accessed on 17.01.2019.]. Available at: https://eurlex.europa.eu/eli/reg/2011/1169/oj

13. WAO (2013) Food Allergy - A Rising Global Health Problem. [accessed on 17.01.2019.]. Available at: https://www.worldallergy.org/UserFiles/file/WorldAllerg yWeek2013final.pdf 